\title{
Probable hepatic capillariosis and hydatidosis in an adolescent from the late Roman period buried in Amiens (France)
}

\author{
Gholamreza Mowlavi ${ }^{1,6}$, Sacha Kacki ${ }^{2}$, Jean Dupouy-Camet ${ }^{3}{ }^{*}$, Iraj Mobedi ${ }^{1}$, Mahsasadat Makki ${ }^{1}$, \\ Majid Fasihi Harandi ${ }^{4}$, and Saied Reza Naddaf ${ }^{5}$ \\ 1 Department of Medical Parasitology and Mycology, School of Public Health, Tehran University of Medical Sciences, PO Box 6446, \\ Tehran 14155, Iran \\ 2 PACEA, UMR 5199, Anthropologie des Populations Passées et Présentes, Université de Bordeaux, Bâtiment B8, \\ Allée Geoffroy St Hilaire, CS 50023, 33615 Pessac Cedex, France \\ 3 Service de Parasitologie-Mycologie, Hôpital Cochin Assistance Publique Hôpitaux de Paris, Université Paris Descartes, \\ 27 Faubourg St Jacques, 75014 Paris, France \\ 4 Research Center for Hydatid Disease in Iran, Kerman University of Medical Sciences, Kerman 76169-14111, Iran \\ 5 Department of Parasitology, Pasteur Institute of Iran, 69 Pasteur Avenue, Tehran 13169-43551, Iran \\ 6 Center for Research of Endemic Parasites of Iran (CREPI), Tehran University of Medical Sciences, PO Box 6446, Tehran 14155, Iran
}

Received 30 October 2013, Accepted 13 February 2014, Published online 28 February 2014

\begin{abstract}
Two calcified objects recovered from a 3rd to 4th-century grave of an adolescent in Amiens (Northern France) were identified as probable hydatid cysts. By using thin-section petrographic techniques, probable Calodium hepaticum (syn. Capillaria hepatica) eggs were identified in the wall of the cysts. Human hepatic capillariosis has not been reported from archaeological material so far, but could be expected given the poor level of environmental hygiene prevalent in this period. Identification of tissue-dwelling parasites such as $C$. hepaticum in archaeological remains is particularly dependent on preservation conditions and taphonomic changes and should be interpreted with caution due to morphological similarities with Trichuris sp. eggs.
\end{abstract}

Key words: Paleoparasitology, Capillariosis, Hydatidosis, Calodium, Capillaria, Echinococcus granulosus.

Résumé - Capillariose et hydatidose hépatiques probables chez un adolescent du bas Empire inhumé à Amiens (France). Deux objets calcifiés découverts dans la tombe d'un adolescent du $3^{\text {ème }}-4^{\text {ème }}$ siècle à Amiens (France) ont été identifiés comme des kystes hydatiques probables. En utilisant des techniques pétrographiques, des œufs de Calodium hepaticum (syn. Capillaria hepatica) ont été identifiés dans la paroi de ces kystes. La capillariose hépatique n'a jamais été rapportée de restes archéologiques mais n'est pas inattendue compte tenu du bas niveau d'hygiène de cette époque. L'identification de parasites tissulaires comme C. hepaticum dans des vestiges archéologiques est particulièrement dépendante des conditions de conservation et de changements taphonomiques et doit être interprétée avec circonspection en raison des similitudes morphologiques de ces œufs avec ceux du trichocéphale (Trichuris sp.).

\section{Introduction}

Paleoparasitology is the identification of parasites found in archaeological material. Sometimes parasitic eggs are relatively well preserved in latrines or mummified bodies, but their identification can be difficult. We report and discuss here the probable occurrence of human hepatic capillariosis associated with hydatidosis in an adolescent from the late Roman period buried in Amiens (Northern France). Although hydatidosis, particularly of the liver, still remains a problem of public health world-

\footnotetext{
*Corresponding author: jean.dupouy-camet@cch.aphp.fr
}

wide [20], human capillariosis is quite infrequent, but could have been more prevalent in ancient times due to greater contact with rodents and low hygiene in general. Calodium hepaticum (syn. Capillaria hepatica, Bancroft, 1893), the causative agent of hepatic capillariosis, is a parasitic nematode of rodents and other mammalian species, including humans. The adult worms invade the liver parenchyma of the host and lay numerous eggs in the surrounding tissues [21]. Hepatic capillariosis is a rare infection in humans and is associated with septal fibrosis of the liver, which leads to cirrhosis in severe infections $[16,22]$. Infection transmission mostly occurs after ingestion

This is an Open Access article distributed under the terms of the Creative Commons Attribution License (http://creativecommons.org/licenses/by/4.0), which permits unrestricted use, distribution, and reproduction in any medium, provided the original work is properly cited. 

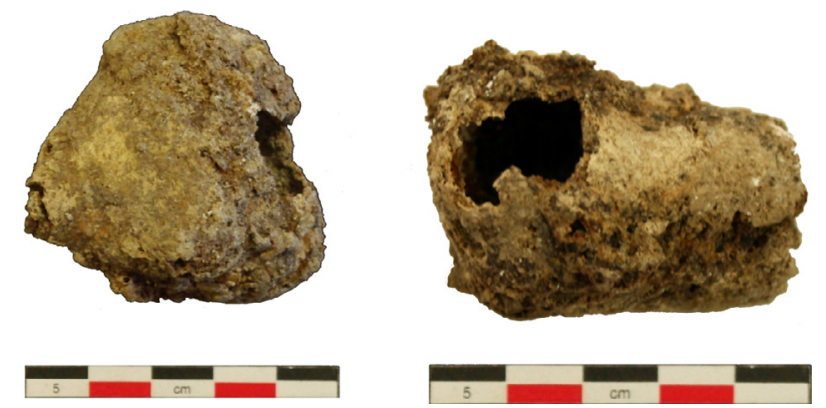

Figure 1. Cysts obtained from the grave of a late Roman adolescent in Amiens, France.

of embryonated eggs, which are disseminated in the soil following decomposition of parasitized dead animals, or in the environment following defecation by predators or scavengers [28]. Diagnosis requires a liver biopsy or post-mortem examination to demonstrate the presence of eggs [27]. The recovery of capillariid eggs from archaeological remains has been recorded: e.g., in human coprolites from the Neolithic inhabitants of Chalain (Jura, France) [7], in a pellet belonging to a Patagonian bird of prey from 6500 years ago [18], in Argentine rodent coprolites from 8000 years ago [33], in non-human organic remains from the French Medieval site of Charavines [5], and from the archaeological layers of "Place d'Armes" (Namur, Belgium) in which seven historical strata exist from the Roman period up to modern times [13].

\section{Materials and methods}

During an excavation in 2009 in the city of Amiens (Northern France) investigators recovered two ovoid cyst-like objects from the grave of an adolescent of unknown sex (Fig. 1). The burial was part of a small necropolis dating back to the Late Roman period ( 3 rd-4th century AD). Although the skeleton was poorly preserved, all bones were connected and the cystic objects were obtained from the thoraco-abdominal region. The calcified objects, measuring $46 \times 46 \times 37 \mathrm{~mm}$ and $47 \times 33 \times 32 \mathrm{~mm}$, respectively, exhibited a rough and irregular outer surface of brown/black color. Several holes in the outer wall revealed a hollow interior, with some powder inside. Contrary to the external surface, the internal surface was smooth. During the initial anthropological study, the aspect of the cysts indicated likely liver hydatidosis. In order to confirm this hypothesis, the cysts and the containing elements were analyzed by X-ray diffraction (XRD) and element analysis by X-ray fluorescence (XRF). X-ray analyses were performed at the Faculty of Sciences, Tarbiat Modares University, Tehran, Iran. To examine the material for parasites, the powder inside the cysts was rehydrated using trisodium phosphate (TSP) aqueous solution, as recommended [8]. In addition, tissue sections were prepared from the wall of the cysts by means of thin-section petrography, a well-established method in geology [10,31,37], but with some modifications. Four pieces of the specimen measuring about $1-2 \times 1.5 \mathrm{~cm}$ were precisely sawed from the cysts, using a 50-cm-long steel wire. Due to the fragility of the specimen, samples were impregnated with resin (Epofix) in a vacuum

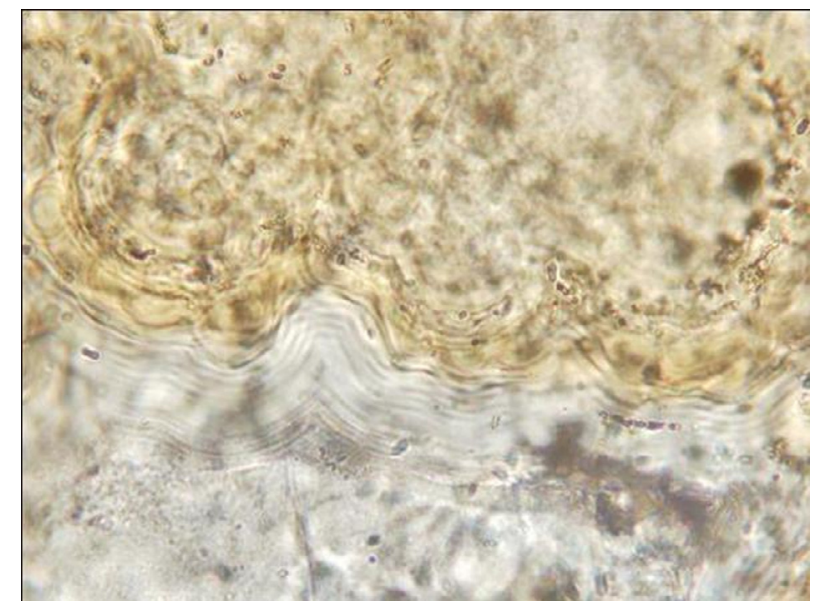

Figure 2. Laminated layers observed on a thin section of the cyst wall suggesting hydatidosis.

chamber for $3 \mathrm{~h}$ and embedding was continued for another $8 \mathrm{~h}$ in the same chamber. Impregnated blocks were smoothed manually on one side and mounted on glass slides with Epofix resin. Grinding to a thickness of 1-2 mm and 50-60 $\mu \mathrm{m}$ was performed by a diamond blade (Microplan-TR) and diamond grinding wheel (Microplan-TR), respectively. Finally, to achieve the $30-\mu \mathrm{m}$ thickness required for light transmission, silicon carbide powder (Mesh Nos. 320, 600, 800, and 1000) was used manually. At the end of each grinding step, coarse material was removed with tap water. Section slide mounting was performed using mixed lowviscosity resin and a cover slip under $0.5 \mathrm{~kg}$ pressure for $2 \mathrm{~h}$. In addition, some parts of the cysts were thoroughly pulverized and rehydrated in TSP solution for 10 days. The parasite eggs were microscopically detected, photomicrographed, and measured using a calibrated microscope.

\section{Results}

For the first cyst, XRD clearly detected the presence of both calcite and apatite (data not shown). These components were also present in the second cyst, together with other crystallographic species (quartz and iron). The XRF analyses showed that the main chemical elements of both cysts were calcium oxide and phosphorus oxide (Table 1). The high concentration of phosphorus in both samples is highly consistent with an organic origin. In addition, in both cysts, the stoichiometry $\mathrm{P} / \mathrm{Ca}$ was compatible with that of hydroxyapatite, which can be considered as the main component of the cyst (or even the only one, if the few other elements are due to telluric pollution). Precise detection of larval rostellar hooks, which could have characterized hydatid cysts, was negative, but in one section a faded structure resembling a hydatid cyst laminated layer was observed (Fig. 2). In addition, capillariid eggs were detected in all 15 thin-section slides and in the rehydrated pulverized cyst. Eggs in the section slides (Figs. 3b-3d) were more transparent than those observed in the rehydrated pulverized cyst (Fig. 3a). The mean length and width of the eggs were 46.7 and $25 \mu \mathrm{m}$, respectively, and these eggs were tentatively 
Table 1. Chemical analysis by X-ray fluorescence of samples from the two cysts.

\begin{tabular}{|c|c|c|c|c|c|c|c|c|c|}
\hline$\%$ & $\mathrm{Na}_{2} \mathrm{O}$ & $\mathrm{MgO}$ & $\mathrm{AlO}_{3}$ & $\mathrm{SiO}_{2}$ & $\mathrm{P}_{2} \mathrm{O}_{5}$ & $\mathrm{SO}_{3}$ & $\mathrm{CaO}$ & $\mathrm{Fe}_{2} \mathrm{O}_{3}$ & $\mathrm{Sr}$ \\
\hline Cyst 1 & 0.19 & 0.42 & 0.15 & 0.85 & 37.9 & 0.3 & 59.6 & 0.39 & 0.07 \\
\hline Cyst 2 & 0.24 & 0.58 & 2.1 & 20.4 & 18.9 & 0.36 & 54.2 & 1.7 & 0.08 \\
\hline
\end{tabular}
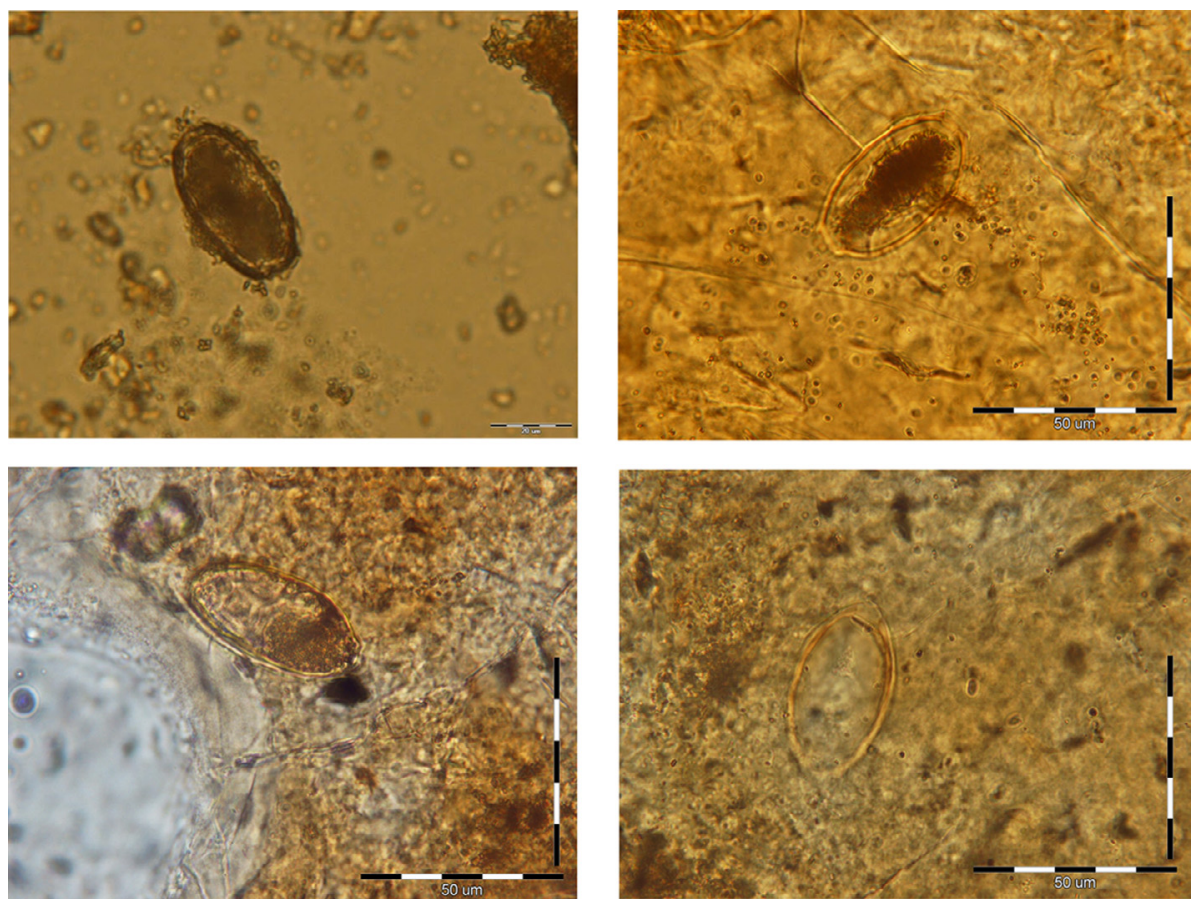

Figure 3. Probable Calodium hepaticum eggs detected in the rehydrated pulverized cyst (a) and in thin-section slides (b-d). Scale bars $=50 \mu \mathrm{m}, \mathrm{a}-\mathrm{d}$ : from top to base.

identified as C. hepaticum. No parasite remains or eggs were seen in the powder from inside the cysts.

\section{Discussion}

These findings support the biological origin of the two cysts, as apatite is the main component of bones and teeth [38] and is also commonly found in tissue calcifications linked to various pathological conditions [25]. The mineral composition of the cysts, their location, their morphology, and the observation of a laminated layer are compatible with the diagnosis of liver hydatidosis $[3,25]$. However, in the absence of larval rostellar hooks, only DNA-based techniques would allow a definitive diagnosis. Hydatid cysts frequently undergo calcification, and numerous ancient cases have been reported from Europe $[3,24,30,39]$. The morphological characteristics of these published examples - ovoid, hollow concretions with a smooth internal surface and an irregular external surface - are quite similar to those of the two calcified objects reported here. These morphological features rule out most of the other diagnostic options, such as calcified objects that are solid (e.g., urinary or renal calculi, uterine leiomyoma, dermoid cysts), that are not expected to be so large (e.g., calcified lymph nodes), or which exhibit imprints of vascularization (e.g., calcified ovarian cysts) $[2,23]$. Calcification of internal organs, induced by a normal taphonomic process after a long burial, seems quite unlikely according to the experience of one of the authors of the present work. Finally, although we cannot definitely exclude that the cysts underwent migration within the body during its decomposition, their location in the thoraco-abdominal region of the skeleton is again compatible with liver hydatidosis. The attachment of the cysts to the liver parenchyma would explain why $C$. hepaticum eggs were found in the wall of these cysts. A review of the literature shows that the only archaeological materials in which capillariid eggs have been detected so far are human coprolites, sediment of sewage structures, and garbage dumps $[4,9,13]$. Within these types of archaeological remains a definite diagnosis of human hepatic capillariosis could not be concluded. The finding of capillariid eggs in human coprolites can be explained by the transitional passing of parasite eggs, following the ingestion of an infected animal liver [17], as reported among Indians of the Amazonian region [12]. The proof of hepatic capillariosis in archaeological remains would only be possible through the examination of remaining tissues in mummified bodies, or by analyzing exceptional samples like the ones isolated in Amiens. In all 15 slides, several C. hepaticum eggs were detected possessing the main characters of Calodium hepaticum eggs, such as a double barrelshape, pitted shell, polar plugs not extending beyond the outline 
shell and radiation between the external layers [19, 21, 34]. However, due to ultra-structural changes that may occur to helminth eggs over a long period of time [6], all morphological and morphometric features were not simultaneously observed in individual eggs. The mean length and width of the recovered eggs $(46.7$ and $25 \mu \mathrm{m})$ are in agreement with the findings reported by others $[21,26]$. The thoraco-abdominal location of the examined cysts, besides the findings presented here, are altogether in favor of a true hepatic capillariosis. Actually, Capillaria-like eggs have already been found in human graves, but in that report the authors suggested secondary contamination by feces of rodents [15]. In our case, this type of contamination can be excluded, as the eggs were found in the wall of the cysts. Another possibility could be the contamination of the cysts by Trichuris trichiura (Linnaeus, 1771) eggs from the intestine of the young adolescent. However, Trichuris sp. eggs have thicker shells and are usually very well preserved (in particular the polar plugs) as, for example, in the famous Ötzi mummy dating from the Neolithic times [1], or in the French Medieval site of Charavines [5]. The possibility of infection with Eucoleus aerophilus (Creplin, 1839), another capillariid parasite with morphologically similar eggs, could be ruled out as eggs of this parasite are larger $(60-83 \times 25-40 \mu \mathrm{m})$ and have asymmetric polar plugs [36]. Human hepatic capillariosis can be acquired under various circumstances, including high exposure to rodent populations and poor hygiene [35]. Soil, vegetables, and water contaminated by rat feces containing embryonated eggs are known sources of infection [16, 29]. In ancient times due to the lack of public health awareness the incidence of hepatic capillariosis could have been more significant than today, as only 37 case reports of human $C$. hepaticum infection have been reported up to 2010 [17, 26]. Moreover, new findings of $C$. hepaticum infection in mice in humaninhabited houses in Portugal [32] and the respective prevalence of $36 \%$ and $44 \%$ Capillaria infection of rats in Italy [11] and Marseille [14], respectively, support the idea of the possible frequent occurrence of human hepatic capillariosis in the 3rd-4th century AD. This work revealed that the petrographic thinsection technique is an efficient tool for identification of hepatic capillariosis and other tissue-dwelling parasites in very old organic remains, as well as in fossilized specimens. This current observation illustrates quite well the difficulties of differential diagnosis in paleoparasitology, related to the resemblance of the eggs of different species of capillariids. It underlines the usefulness of a precise registration of the position of samples within the skeleton and the possible influence of taphonomic processes in the modification of egg morphology. Finally, this case of probable liver hydatidosis is certainly the most ancient reported so far in France.

Acknowledgements. We thank Mr. Vincent Lascour (Institut National de Recherches Archéologiques Préventives, Amiens), who directed the archaeological excavation and entrusted us with the study of the two calcified objects. We are also very grateful to Dr. Abdolhosein Aminyat of the Faculty of Science, Tehran University, and Mr. Hamid Sojiudi, Teyfazarin Company, Tehran, Iran, for their technical assistance in using the petrographic thin-section method. Dr. Armel Bouvier (CIRAM, Talence, France) and Mr. Mehdi Saffari (Faculty of Sciences, Tarbiat Modares University, Tehran, Iran) are acknowledged for XRD and XRF interpretation and analy- sis. Special thanks also to Dr. Zohreh Eslami Rasekh at Texas A\&M University and Dr. Gordon Langsley (Cochin Institute) for revising the manuscript. This article was published with the help of ADERMEPT (Association pour le Développement et la Recherche en Médecine Tropicale) and ACMSFI (Association de Coopération Médico Scientifique Franco Iranienne).

\section{References}

1. Aspök H, Auer H, Picher O. 1996. Trichuris trichiura eggs in the Neolithic glacier mummy from the Alps. Parasitology Today, 12, 255-256.

2. Aufderheide AC, Rodríguez-Martín C. 1998. The Cambridge Encyclopedia of Human Paleopathology. Cambridge University Press: Cambridge.

3. Baud CA, Kramar C. 1990. Les calcifications biologiques en archéologie. Bulletins et Mémoires de la Société d'Anthropologie de Paris, 2, 163-170.

4. Bouchet F, Harter S, Le Bailly M. 2003. The state of the art of paleoparasitological research in the Old World. Memórias do Instituto Oswaldo Cruz, 98, 95-101.

5. Bouchet F, Lavazec C, Nattier V, Dommelier S, Bentrad S, Paicheler JC. 2000. Étude de la parasito-faune du site médiéval de Charavines (lac de Paladru, Isère, France). Bulletin de la Société zoologique de France, 125, 205-215.

6. Bouchet F, Lefèvre C, West D, Corbett D. 1999. First paleoparasitological analysis of a midden in the Aleutian Islands (Alaska): results and limits. Journal of Parasitology, 85, 369-372.

7. Bouchet F. 1997. Intestinal capillariasis in neolithic inhabitants of Chalain (Jura, France). Lancet, 349, 256.

8. Callen EO, Cameron T. 1960. A prehistoric diet revealed in coprolites. New Scientist, 8, 35-40.

9. Carvalho ML, Araújo A, Ferreira LF. 2003. Human intestinal parasites in the past: new findings and a review. Memórias do Instituto Oswaldo Cruz, 98 (Suppl. 1), 103-118.

10. Carver RE. 1971. Procedures in sedimentary petrology. Wiley Interscience: New York.

11. Ceruti R, Sonzogni O, Origgi F, Vezzoli F, Cammarata S, Giusti AM, Scanziani E. 2001. Capillaria hepatica infection in wild brown rats (Rattus norvegicus) from the urban area of Milan, Italy. Journal of Veterinary Medicine B. Infectious Diseases and Veterinary Public Health, 48, 235-240.

12. Coimbra Júnior CE, Mello DA. 1981. Enteroparasites and Capillaria sp. found in Indians of the Surui group, Parque Indigena Aripuana, Rondonia. Memórias do Instituto Oswaldo Cruz, 76, 299-302.

13. da Rocha GC, Harter-Lailheugue S, Le Bailly M, Araújo A, Ferreira LF, da Serra-Freire NM, Bouchet F. 2006. Paleoparasitological remains revealed by seven historic contexts from "Place d'Armes", Namur, Belgium. Memórias do Instituto Oswaldo Cruz, 101, 43-52.

14. Davoust B, Boni M, Branquet D, Ducos de Lahitte J, Martet G. 1997. Recherche de trois infestations parasitaires chez des rats capturés à Marseille : évaluation du risque zoonosique. Bulletin de l'Académie Nationale de Médecine, 181, 887-895.

15. Dittmar K, Teegen WR. 2003. The presence of Fasciola hepatica (liver-fluke) in humans and cattle from a 4,500 year old archaeological site in the Saale-Unstrut Valley, Germany. Memórias do Instituto Oswaldo Cruz, 98 (Suppl. I), 141-143. 
16. Ferreira LA, Andrade ZA. 1993. Capillaria hepatica: a cause of septal fibrosis of the liver. Memórias do Instituto Oswaldo Cruz, $88,441-447$.

17. Fuehrer HP, Igel P, Auer H. 2011. Capillaria hepatica in manan overview of hepatic capillariosis and spurious infections. Parasitology Research, 109, 969-979.

18. Fugassa M, Sardella N, Denegri G. 2007. Paleoparasitological analysis of a raptor pellet from Southern Patagonia. Journal of Parasitology, 93, 421-422.

19. Fugassa MH, Taglioretti V, Gonçalves ML, Araújo A, Sardella NH, Denegri GM. 2008. Capillaria spp. eggs in Patagonian archaeological sites: statistical analysis of morphometric data. Memórias do Instituto Oswaldo Cruz, 103, 104-105.

20. Grosso G, Gruttadauria S, Biondi A, Marventano S, Mistretta A. 2012. Worldwide epidemiology of liver hydatidosis including the Mediterranean area. World Journal of Gastroenterology, 18, 1425-1437.

21. Gutierrez Y. 1999. Diagnostic pathology of parasitic infections with clinical correlations. Oxford University Press: USA.

22. Kallichurum S, Elsdon-Dew R. 1961. Capillaria in man. South African Medical Journal, 35, 860-861.

23. Komar D, Buikstra J. 2003. Differential diagnosis of a prehistoric biological object from the Koster (Illinois) site. International Journal of Osteoarchaeology, 13, 157-164.

24. Kristjánsdóttir S, Collins C. 2011. Cases of hydatid disease in medieval Iceland. International Journal of Osteoarchaeology, 21, 479-486.

25. Lagier R, Baud CA, Buchs M. 1966. Crystallographic identification of calcium deposits as regards their pathological nature, with special reference to chondrocalcinosis. In Third European Symposium on Calcified Tissues. Fleisch H, Blackwood HJJ, Owen M, Editors. Springer-Verlag: Berlin, Heidelberg, New York, pp. 158-162.

26. Li CD, Yang HL, Wang Y. 2010. Capillaria hepatica in China. World Journal of Gastroenterology, 16, 698-702.

27. Meyers WM. 2000. Pathology of infectious diseases. Helminthiases, Vol. 1. Armed Forces Institute of Pathology: Washington, DC.
28. Mobedi I, Arfaa F. 1971. Probable role of ground beetles in the transmission of Capillaria hepatica. Journal of Parasitology, 57, 1144-1145.

29. Pozio E. 2003. Foodborne and waterborne parasites. Acta Microbiologica Polonica, 52 (Suppl.), 83-96.

30. Price J. 1975. The radiology of excavated Saxon and medieval human remains from Winchester. Clinical Radiology, 26, 363-370.

31. Reed FS, Mergner JL. 1953. Preparation of rock thin sections. American Mineralogist, 38, 1184-1203.

32. Resendes AR, Amaral AF, Rodrigues A, Almeria S. 2009. Prevalence of Calodium hepaticum (Syn. Capillaria hepatica) in house mice (Mus musculus) in the Azores archipelago. Veterinary Parasitology, 160, 340-343.

33. Sardella NH, Fugassa MH, Rindel DD, Goñi RA. 2010. Paleoparasitological results for rodent coprolites from Santa Cruz Province, Argentina. Memórias do Instituto Oswaldo Cruz, 105, 33-40.

34. Silverman N, Katz J, Levin S. 1973. Capillaria hepatica infestation in a child. South African Medical Journal, 47, 219 221.

35. Spratt DM, Singleton GR. 2008. Hepatic capillariasis, in Parasitic Diseases of Wild Mammals. Samuel WM, Pybus MJ, Kocan AA, Editors. Wiley Interscience: New York, pp. 365379.

36. Traversa D, Di Cesare A, Milillo P, Iorio R, Otranto D. 2009. Infection by Eucoleus aerophilus in dogs and cats: Is another extra-intestinal parasitic nematode of pets emerging in Italy? Research in Veterinary Science, 87, 270-272.

37. Tucker ME. 1988. Techniques in sedimentology. Blackwell Science: London.

38. Tuross N. 2003. Recent advances in bone, dentin, and enamel biochemistry, in Identification of pathological conditions in human skeletal remains. Ortner DJ, Editor. Academic Press: New York, pp. 65-72.

39. Weiss DL, Møller-Christensen V. 1971. Leprosy, echinococcosis and amulets: a study of a medieval Danish inhumation. Journal of Medical History, 15, 260-267.

Cite this article as: Mowlavi G, Kacki S, Dupouy-Camet J, Mobedi I, Makki M, Harandi MF \& Naddaf SR: Probable hepatic capillariosis and hydatidosis in an adolescent from the late Roman period buried in Amiens (France). Parasite, $2014,21,9$.

Reviews, articles and short notes may be submitted. Fields include, but are not limited to: general, medical and veterinary parasitology; morphology, including ultrastructure; parasite systematics, including entomology, acarology, helminthology and protistology, and molecular analyses; molecular biology and biochemistry; immunology of parasitic diseases; host-parasite relationships; ecology and life history of parasites; epidemiology; therapeutics; new diagnostic tools.

All papers in Parasite are published in English. Manuscripts should have a broad interest and must not have been published or submitted elsewhere. No limit is imposed on the length of manuscripts.

Parasite (open-access) continues Parasite (print and online editions, 1994-2012) and Annales de Parasitologie Humaine et Comparée (1923-1993) and is the official journal of the Société Française de Parasitologie. 